Vol. 1, 2019

E-ISSN: 2715-002X

\title{
Psikososial Tradisi Menjadi Pengemis di Desa Pragaan Daya Kecamatan Pragaan Kabupaten Sumenep
}

\author{
Nawafil $^{1}$, Suryanto ${ }^{2}$, Eko April Ariyanto ${ }^{3}$ \\ ${ }^{123}$ Fakultas Psikologi Universitas 17 Agustus 1945 Surabaya \\ email: nawafil_s2@untag-sby.ac.id ${ }^{1}$, suryanto@psikologi.unair.ac.id ${ }^{2}$, \\ arjo.merdeka@gmai.com ${ }^{3}$
}

\begin{abstract}
Abstrak
Penelitian ini bertujuan untuk mengetahui Bagaimana perilaku mengemis warga desa Pragaan Daya, Apa saja faktor yang melatarbelakangi mereka melakukan kegiatan mengemis, Mengapa kegiatan mengemis bisa menjadi tradisi pada masyarakat Pragaan Daya. Pendekatan penelitian yang digunakan adalah kualitatif dengan metode Etnografi yaitu peneliti melakukan studi yang sangat mendalam tentang perilaku yang terjadi secara alami di sebuah budaya atau sebuah kelompok sosial tertentu untuk memahami sebuah budaya tertentu dari sisi pandang pelakunya. Lokasi penelitian di Desa Pragaan Daya Kecamatan Pragaan Kabupaten Sumenep. Teknik pengumpulan data yang digunakan adalah observasi, wawancara, dan dokumentasi. Teknik analisis data dengan pengumpulan data, reduksi data, penyajian data dan penarikan kesimpulan. Hasil dari penelitian ini menunjukkan Bentuk perilaku mengemis warga Desa Pragaan Daya bervariasi, seperti door to door, duduk di tempat-tempat keramaian, membawa proposal dan memakai kotak amal. Perilaku mengemis di Desa Pragaan Daya secara umum dilatarbelakangi oleh motif ekonomi dan sosila budaya. Motivasi ekonomi ini berkaitan dengan cara memperoleh uang dengan mudah, memakai modal yang sedikit, serta bisa memperoleh keuntungan yang besar. Adapun motivasi sosial budaya berkaitan dengan kebiasaan mengemis yang dilakukan kebanyakan warga, yang lama kelamaan mempengaruhi warga yang lain untuk meniru perilaku mengemis. Pemahaman mengenai cara mencari nafkah dengan jalan mengemis sudah tertanam lama dari satu generasi ke generasi. Para sesepuh memberikan indoktrinasi bahwa pilihan pekerjaan untuk bertahan hidup yang bisa mereka lakukan adalah mengemis, sehingga dalam satu keluarga tertanam mental mengemis yang kemudian menjadi sebuah tradisi dan pada akhirnya kegiaatan mengemis menjadi profesi dan ladang bisnis bukan lagi karena faktor kemiskinan
\end{abstract}

Kata kunci: Psikososial, Tradisi, Pengemis

Dipresentasikan dalam Seminar Nasional "Membangun Resiliensi di Era Revolusi Industri 4.0" Fakultas Psikologi Unissula. 22 September 2019 
PSISULA: Prosiding Berkala Psikologi

Vol. 1, 2019

E-ISSN: 2715-002X

\section{Pendahuluan}

Perilaku mengemis merupakan gambaran dari masyarakat kurang mampu yang mengais rezeki dengan mengharap belas kasihan dari orang lain. Perilaku mengemis melahirkan sebuah persepsi kurang menyenangkan, baik dari sisi sosial maupun ekonomi. Fenomena munculnya pengemis secara umum diindikasikan karena tuntutan ekonomi yang disebabkan sempitnya lapangan kerja, sumber daya alam yang kurang menguntungkan, dan lemahnya sumber daya manusia.

Namun, asumsi tersebut saat ini mulai memudar seiring perkembangan waktu. Meskipun selalu ada persepsi bahwa pengemis itu miskin, namun tidak halnya dengan fakta yang ada. Sebab, perilaku mengemis saat ini telah bergeser makna dan orientasinya. Mengemis tidak lagi menjadi sebuah keterpaksaan dalam memenuhi kebutuhan hidup, namun merupakan pilihan pekerjaan yang menjanjikan. Sebab, dengan modal yang relatif sedikit, mengemis dapat menghasilkan keuntungan yang lumayan cukup memuaskan.

Dilihat dari kehidupan sosial ekonomi, masyarakat desa Pragaan Daya tidaklah terlalu miskin. Sebagaimana warga desa lainnya, kehidupan ekonomi masyarakat ini sebagaimana standar masyarakaat pada umumnya. Bahkan, ada sebagian yang di atas standar tersebut.

Praktek mengemis merupakan masalah sosial, di mana mereka dianggap telah menyimpang dari nilai dan norma-norma yang berlaku. Mereka adalah orang sehat dengan kondisi tubuh yang tidak kurang apapun (Bina Desa, $1987: 3$ ).

Dari fenomena di atas, muncul pertanyaan mengapa masyarakat Pragaan Daya mau menekuni profesi menjadi pengemis sedagkan dari segi ekonomi ratarata meraka berkecukupan, bahkan menjadi tradisi dari satu generasi ke generasi berikutnya, dan nilai-nilai apa yang disosialisasikan sehingga mendorong mereka berprofesi sebagai pengemis.

Penelitian ini difokuskan untuk melihat secara etnografis berbagai hal mengenai perilaku dan model-model mengemis di Desa Pragaan Daya, mengapa 
PSISULA: Prosiding Berkala Psikologi

Vol. 1, 2019

E-ISSN: 2715-002X

mereka mau berprofesi sebagai pengemis dan bagaimana proses sosialisasi perilaku mengemis terjadi baik pada lingkup keluarga maupun di dalam lingkup masyarakat di desa tersebut.

\section{Metode Penelitian}

Penelitian ini menggunakan pendekatan kualitatif, sebuah pendekatan yang menempatkan pandangan peneliti terhadap sesuatu yang diteliti secara subyektif, dalam arti peneliti sangat menghargai dan memperhatikan pandangan subyektif setiap subyek yang ditelitinya.

Pendekatan kualitatif selalu berusaha memahami pemaknaan individu (subjective meaning) dari subyek yang ditelitinya. Karena itu, peneliti melakukan interaksi atau komunikasi yang intensif dengan pihak yang diteliti, termasuk di dalamnya peneliti harus mampu memahami dan mengembangkan kategorikategori, pola-pola dan analisa terhadap proses-proses sosial yang terjadi di tengah masyarakat yang diteliti (Creswell, 1994; 157-159).

Penggunaan pendekatan kualitatif ini didasarkan pada pertimbangan bahwa; Pertama, fenomena yang hendak diteliti merupakan gejala sosial yang dinamis, sehingga ia senantiasa merupakan proses sosial yang berkembang secara dinamis. Kedua, materi (subject matter) dalam penelitian ini menyangkut proses dari suatu tindakan yang ditunjukkan oleh gejala-gejala berupa pemikiran, ucapan dan tindakan yang dilakukan oleh anggota suatu kelompok masyarakat, dalam hal ini para pengemis. Karena itu, mengacu kepada Creswell bahwa perhatian utama dari peneliti-peneliti kualitatif adalah berkaitan dengan proses-proses yang terjadi, bukan out put atau hasil. Peristiwa-peristiwa yang terjadi dalam masyarakat pengemis dipahami dan dimaknai, sehingga sedapat mungkin menggambarkan realitas yang sebenarnya.

Alasan yang ketiga, lebih merupakan pertimbangan subyektif peneliti, bahwa peristiwa-peristiwa yang terjadi di lapangan penelitian atau proses sosial yang hendak diteliti mencakup proses yang kompleks, dan baru bisa dipahami dengan 
PSISULA: Prosiding Berkala Psikologi

Vol. 1, 2019

E-ISSN: 2715-002X

baik apabila data dan informasinya dipaparkan secara lengkap dengan mengembangkan kategori-kategori yang relevan dengan analisis interpretatif.

Sedangkan tipe penelitian yang digunakan adalah deskriptif analitis dengan teknik pengumpulan data melalui wawancara mendalam (indepth interview) kepada para tokoh masyarakat setempat, para pemerhati sosial khususnya yang pernah melakukan penelitian sejenis, dan pengemis sebagai aktor. Penentuan calon informan dilakukan berdasarkan metode bola salju (snow ball), yakni berdasarkan informasi yang diberikan oleh informan terdahulu, sehingga dari informan yang satu ke informan yang lain dapat diperoleh informasi yang semakin lengkap. Peneliti ini juga melakukan studi terhadap berbagai literatur dan dokumen yang ada, serta observasi untuk melihat bagaimana para pengemis Desa Pragaan Daya menata kegiatan mereka, termasuk bagaimana mengelola kehidupan ekonomi.

\section{Hasil Penelitian}

\section{Perilaku Mengemis Masyarakat Pragaan Daya}

Menurut Humaidi dalam Yuniarti (2013:3), jenis praktik mengemis dilakukan biasanya secara individual, baik dalam hal keberangkatan maupun penentuan daerah mengemis. Keuntungan individual ini adalah kebebasan menggunakan hasil yang diperoleh. Dalam menjalankan pekerjaannya, model dan strategi yang dilakukan oleh pengemis antara lain sebagai berikut.

a) Door to door (pintu ke pintu)

Para pengemis menggunakan strategi ini untuk mendatangi rumah, kantorkantor, toko-toko, warung dan bengkel yang ada di pinggiran jalan

b) Menanti di depan bangunan yang ramai dikunjungi orang

Mereka hanya duduk di tempat yang biasanya ramai pengunjung dan menadahkan tangan kepada setiap orang yang lewat (Observasi 12 Juni 2019).

c) Model Proposal

Dipresentasikan dalam Seminar Nasional "Membangun Resiliensi di Era Revolusi Industri 4.0" Fakultas Psikologi Unissula. 22 September 2019 
PSISULA: Prosiding Berkala Psikologi

Vol. 1, 2019

E-ISSN: 2715-002X

Penggunaan proposal pembangunan digunakan dalam penggalian dana terlebih dahulu adanya perjanjian yang mengatur hak dan kewajiban antara panitia pembangunan dengan pelaksana pencari sedekah. Panitia memberikan sarana berupa proposal dan bertanggung jawab penuh untuk melakukan advokasi dan mengambil orang yang mencari dana tersebut seandainya mereka sampai ditangkap warga, perangkat desa, atau aparat keamanan di tempat wilayah pencari dana melakukan operasi.

Proposal yang dibawa adalah asli, berikut alamat dan nomor telepon panitia tersebut. Sebab, tidak jarang masyarakat melakukan crossceck melalui telepon terhadap proposal yang dibawa. Dalam hal ini, panitia menjawab dan melindungi orang yang membawa proposal tersebut. Adapun kewajiban dari pembawa proposal tersebut adalah sejak proposal diserahterimakan dari panitia, maka ada kewajiban untuk memberikan uang setoran Rp. 20.000,- (dua puluh ribu rupiah) perhari. Setorannya bisa harian, bisa juga mingguan, bahkan ada juga yang bulanan, tergantung akad dan daya jelajah para "pengemis" tersebut (Wawancara dengan Haris, 22 Juni 2019).

d) Kotak Amal

Modus menggunakan kotak amal dalam mencari sedekah merupakan cara lama yang dilakukan oleh mereka. Para pencari sedekah menggunakan pola secara berkelompok, 3 orang sampai dengan 5 orang, yang menyebar ke setiap penjuru gang di wilayah sasaran operasinya. Dalam melakukan operasi, mereka tidak membedakan sasarannya, apakah rumahnya bagus, sedang, atau jelek sekalipun. Semua rumah warga didatangi dengan menyodorkan kotak amal yang sudah dibawa.

Kecenderungannya adalah tanpa banyak komentar dan penjelasan dan hanya menggunakan bahasa isyarat dengan menyodorkan kotak amal yang dibawa kepada warga. Kalau ada yang bertanya, digunakan untuk apa penggalangan dana tersebut, barulah mereka menjelaskan sekadarnya. Prinsip ekonomi yang dipakai adalah mengejar kuantitas, dalam arti sasarannya bukanlah para 
PSISULA: Prosiding Berkala Psikologi

Vol. 1, 2019

E-ISSN: 2715-002X

penyumbang atau donatur kelas atas yang biasa memberikan jumlah besar, namun hanya berkelas antara Rp. 1.000,- sampai Rp. 5.000,- yang penting mayoritas masyarakat yang menjadi sasarannya rata-rata memberikan sedekahnya. Bisa dibayangkan kalau dalam satu gang ada 10 orang yang memberikan sedekah dengan jumlah nominal Rp. 1.000,- perorang, sedangkan dalam dalam sehari mereka bisa mengitari berpuluh-puluh gang, berapa hasil yang bisa diperoleh dalam sehari.(Wawancara dengan Rasyidi, 27 Juni 2019).

\section{Faktor yang Memengaruhi Perilaku Mengemis}

Secara teoritis, perilaku seseorang itu dipengaruhi oleh dua faktor, yaitu faktor internal dan faktor eksternal. Faktor internal meliputi motivasi, persepsi, pemahaman, dan gejala psikologis lainnya. Dalam kasus ini, faktor motivasi merupakan motif atau dorongan yang menjadikan mereka menjadi pengemis. Dari beberapa informan yang ada, faktor ekonomi menjadi motivasi paling banyak yang menjadi pendorong menjadi pengemis.

Adapun faktor eksternal yang ikut berpengaruh terhadap perilaku pengemis ini di antaranya faktor lingkungan dan budaya. Lingkungan sosial yang ada sangat menyuburkan perilaku pengemis ini. Lingkungan keluarga juga memberikan andil dalam memengaruhi pengemis ini. Bebera kasus menunjukkan bahwa perilaku pengemis ini dilakukan oleh satu keluarga. Misalnya oleh suami-istri, bapak-anak, kakak-adik, dan sebagainya.

- Ekonomi

Menurut toeri yang ada, faktor kemiskinan sangat memengaruhi terjadinya perilaku seseorang yang ujungnya adalah munculnya fenomena peminta-minta atau pengemis. Semakin banyak jumlah orang miskin, semakin potensial mereka menjadi pengemis. Dalam bahasa pembangunan, terjadinya kebergantungan ekonomi pada orang lain yang semakin tinggi.

Akan tetapi kondisi perekonomian mayoritas masyarakat yang menjadi pengemis di desa Pragaan Daya rata-rata sangat berkecukupan dan jauh dari garis kemiskinan. 
PSISULA: Prosiding Berkala Psikologi

Vol. 1, 2019

E-ISSN: 2715-002X

Penghasilan yang mereka dapatkan juga tergolong fantastis. Manifestasi dari hasil mengemis berupa rumah, kendaraan bermotor seperti sepeda motor atau mobil dan beberapa hewan ternak seperti sapi. Sehingga kegiatan mengemis masyarakat Pragaan Daya saat ini bukan lagi karna faktor kemiskinan melainkan lebih kepada profesi yang menjadi tradisi sehingga menjadi ladang bisnis.

\section{- Budaya}

Kebudayaan didefinisikan sebagai keseluruhan pengetahuan manusia sebagai makhluk sosial yang digunakannya untuk memahami dan menginterprestasikan lingkungan dan pengalamannya, serta menjadi landasan bagi tingkah lakunya.

Bila kita kaitkan dengan persoalan mengemis, maka mengemis adalah sebuah profesi yang menjadi penopang hidupnya sehari-hari. Artinya, memang pada dasarnya mental pengemis telah dimiliki oleh orang-orang tersebut, seperti malas bekerja keras, namun berharap mendapatkan penghasilan yang banyak. Akhirnya, untuk memenuhi kebutuhan hidupnya, mereka hanya menggantungkan diri dari pekerjaannya sebagai seorang pengemis dan tidak ada pemasukan dari pekerjaan yang lain. Sebab, memang pada dasarnya pekerjaan ini sangat menggiurkan, terutama pada segi pendapatan yang lumayan besar dengan tenaga yang relatif kecil. Daya tarik itulah yang menjadikan mereka secara terus-menerus tergantung dan menekuni profesi ini.

- Sosial

Interaksi sosial merupakan sutau hubungan sosial yang dinamis antara orang perseorangan, antara perseorangan dengan kelompok, dan antara kelompok dengan kelompok. Hubungan timbal balik tersebut terkadang tanpa sadar telah menjadi sebuah faktor yang di dalamnya secara tidak langsung menjadi sebuah proses memengaruhi.

\section{Tradisi Mengemis}

Nilai-nilai tentang kepengemisan di Desa Pragaan Daya, disosialisasikan melalui kehidupan keluarga. Seperti dituturkan oleh informan Bahri (Wawancara, 
PSISULA: Prosiding Berkala Psikologi

Vol. 1, 2019

E-ISSN: 2715-002X

Tanggal 20 Juni 2019) yang menyatakan bahwa mencari rezeki dengan jalan mengemis bagi masyarakat Pragaan Daya tidak dianggap sebagai sesuatu yang hina. "Bagi kami pekerjaan mengemis bukanlah nista, karena ini juga jalan yang halal. Apalagi kami sadar bahwa mencari pekerjaan sekarang ini sangat sulit".

Karena itu pemahaman mengenai cara mencari nafkah dengan jalan mengemis pun sudah tertanam lama dari satu generasi ke generasi. Para sesepuh memberikan indoktrinasi bahwa pilihan pekerjaan untuk bertahan hidup yang bisa mereka lakukan adalah mengemis, maka wajar bila dalam satu keluarga tertanam mental mengemis. Sosialisasi mengenai hal ini terus berlangsung dan tak pernah ada yang mempersoalkan sehingga tradisi mengemis tetap berlangsung hingga saat ini.

\section{Diskusi}

Ada tiga penyebab kemiskinan menurut Sharp, et.al (dalam Kuncoro, 1997:131) Pertama, keterbatasan sumberdaya alam. Kedua, Kualitas sumberdaya manusia yang rendah karena rendahnya pendidikan, nasib yang kurang beruntung dll. Ketiga, kemiskinan muncul akibat perbedaan akses dalam modal.

Melihat kondisi ekonomi mayoritas masyarakat yang menjadi pengemis di desa Pragaan Daya rata-rata sangat berkecukupan dan jauh dari garis kemiskinan. Serta mempunyai aset berharga seperti rumah, kendaraan bermotor seperti sepeda motor atau mobil dan beberapa hewan ternak seperti sapi serta sebidang tanah. Juga didukung dengan sumber daya manusianya yang mumpuni dilihat dari tingkat pendidikannya yang saat ini sudah banyak sarjana dalam berbagai disiplin ilmu. Aset tersebut sebenarnya sudah bisa dijadikan modal untuk membuka usaha sendiri sehingga memungkinkan struktur dan status sosialnya menjadi terangkat akan tetapi msyarakat Pragaan Daya tetap menjadikan kegiatan mengemis sebagai profesinya.

Sehingga kegiatan mengemis masyarakat Pragaan Daya saat ini bukan lagi karna faktor kemiskinan melainkan lebih kepada profesi yang menjadi tradisi 
PSISULA: Prosiding Berkala Psikologi

Vol. 1, 2019

E-ISSN: 2715-002X

sehingga menjadi ladang bisnis untuk mendapatkan penghasilan yang ditargetkan tanpa menghiraukan status sosialnya, masyarakat Pragaan Daya tidak terlalu memperdulikan jenis pekerjaan untuk memperoleh sesuatu tetapi lebih memperdulikan hasil yang ditargetnya seperti punya rumah yang bagus, punya mobil, dsb. tidak peduli ia mendapatkannya dari hasil bekerja yang dianggap rendahan seperti mengemis atau meminta-minta pada orang lain.

Kegiatan mengemis diyakini oleh masyarakat Pragaan Daya bukanlah pekerjaan yang hina akan tetapi lebih baik daripada mencuri, sedangkan agama yang dianut masyarakat Pragaan Daya adalah Islam yang di dalamnya juga ditanamkan norma-norma yang baik diantaranya adalah "Tangan yang di atas lebih baik daripada tangan yang dibawah" sebagaimana hadits nabi yang diriwayatkan oleh Imam Bukhari dalam al-Bukhari: 1339;

عَنْ عَبْدِ اللَّهِ بْنِ عُمَرَ رَضِيَ اللَّهُ عَنْهُمَا: أَنَّ رَسُولَ اللَّهِ صَلَّى اللَّهُ عَلَيْهِ وَسَلَّمَ قَالَ: الْيَدُ الْعُلْيَا خَيْرٌ مِنْ الْيَدِ

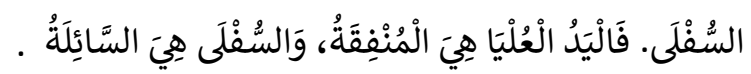

Artinya: Dari Abdullah ibn Umar radhiyallahu 'anhu: Bahwa Rasulullah bersabda: Tangan yang diatas lebih baik daripada tangan yang di bawah. Tangan yang diatas adalah yang memberi (mengeluarkan infaq) sedangkan tangan yang di bawah adalah yang meminta.

Pesan hadits yang disampaikan adalah: 1) Anjuran untuk memberi dan tidak meminta-minta. 2) Motivasi agar kita bekerja dan berusaha mencari nafkah, agar bisa menjadi tangan yang di atas dan memberi orang lain yang membutuhkan.

Masyarakat Pragaan Daya Percaya bahwa memberi itu lebih baik dari meminta akan tetapi tetap melakukan pekerjaan mengemis sehingga bertolak belakang dengan norma agama yang dianutnya yang dalam ilmu psikologi disebut Desonansi Kognitif, sebagai mana Leon Festinger (1957), berpendapat bahwa disonansi terjadi apabila terdapat hubungan yang bertolak belakang, yang diakibatkan oleh penyangkalan dari satu elemen kognitif terhadap elemen lain, antara elemen-elemen kognitif dalam diri individu. Hubungan yang bertolak

Dipresentasikan dalam Seminar Nasional "Membangun Resiliensi di Era Revolusi Industri 4.0" Fakultas Psikologi Unissula. 22 September 2019 
PSISULA: Prosiding Berkala Psikologi

Vol. 1, 2019

E-ISSN: 2715-002X

belakang tersebut, terjadi bila ada penyangkalan antara elemen kognitif yang satu dengan yang lain.

\section{Kesimpulan}

Bentuk perilaku pengemis warga Kecamatan Pragaan Kabupaten Sumenep bervariasi, seperti door to door, duduk di tempat-tempat keramaian, membawa proposal dan memakai kotak amal. Modus yang sangat digemari oleh generasi saat ini adalah membawa proposal untuk pembangunan masjid, pondok pesantren dan sebagainya. Mereka menyetorkan sejumlah uang yang telah ditentukan panitia, sedangkan sisanya adalah hak dari pelaku. Cara ini dianggap paling mudah dan relatif menghasilkan keuntungan yang besar.

Perilaku mengemis yang dilakukan oleh sebagian warga Kecamatan Pragaan Kabupaten Sumenep secara umum dilatarbelakangi oleh motif ekonomi dan sosila budaya. Motivasi ekonomi ini berkaitan dengan cara memperoleh uang dengan mudah, memakai modal yang sedikit, serta bisa memperoleh keuntungan yang besar. Adapun motivasi sosial budaya berkaitan dengan kebiasaan yang dilakukan sebagian warga yang lama kelamaan mempengaruhi warga yang lain untuk meniru perilaku mengemis.

Pemahaman mengenai cara mencari nafkah dengan jalan mengemis sudah tertanam lama dari satu generasi ke generasi. Para sesepuh memberikan indoktrinasi bahwa pilihan pekerjaan untuk bertahan hidup yang bisa mereka lakukan adalah mengemis, sehingga dalam satu keluarga tertanam mental mengemis yang kemudian menjadi sebuah tradisi dan pada akhirnya kegiaatan mengemis menjadi profesi dan ladang bisnis bukan lagi karena faktor kemiskinan. 
PSISULA: Prosiding Berkala Psikologi

Vol. 1, 2019

E-ISSN: 2715-002X

\section{Daftar Pustaka}

Creswell, J. W., (1994). Research Design: Qualitative and Quantitative Approaches. London: Sage Publications.

Festinger, Leon. (1957). A Theory of Cognitive Dissonance. Stanford, CA: Stanford University Press.

Hadits Shahih Al-Bukhari No. 1339 - Kitab Zakat.

Home. (1974). Javanese-English Dictionary, New Haven: Yale University Press.

Prawiroatmodjo, S., (1981). Bausastra Jawa-Indonesia. Jakarta: Gunung Agung.

Purwadi. (2004). Kamus Jawa-Indonesia. Yogyakarta: Media Abadi.

Purwardarminta. (1976). Kamus Umum Bahasa Indonesia. Jakarta: Balai Pustaka, 1976.

Pusat Pembinaan dan Pengembangan Bahasa. (2003). Kamus Besar Bahasa Indonesia. Jakarta: Balai Pustaka.

Umam, Saiful. (2010). “Ngemis: Bermula dari Santri”, Artikel, 4 Agustus.

Wawancara dengan Bahri, Tanggal 20 Juni 2019.

Wawancara dengan Haris, Tanggal 22 Juni 2019.

Wawancara dengan Rasyidi, Tanggal 27 Juni 2019.

Yuniarti, Lita. (2013). Jurnal Ilmiah: Perilaku Pengemis di Alun-Alun Kota Probolinggo. http://repository.unej.ac.id 